\title{
Stocks and Storage Behavior of Traders in Ghana: Insights from a Trader Survey
}

\author{
Lukas Kornher and Felix A. Asante
}

\subsection{Introduction and Motivation}

Grain markets in many African countries exhibit large price volatility which is driven by strong seasonality. Seasonal production and limited storage are identified as major causes of intra-annual price variation (Jones 1972; Sahn and Delgado 1989). Price spikes often occur as a consequence of stock-outs at the end of the marketing season (Shively 2001; Osborne 2004; Tadesse and Guttormsen 2011). The adverse consequences of seasonal hunger and poverty are well acknowledged, and functional markets are recognized as a prerequisite to resolve these problems (Vaitla et al. 2009; Maxwell 2013; van Campenhout et al. 2015).

The structure and efficiency of markets have been improving since the liberalization process in the 1980s. But the price surges and international food crisis in 2007/2008 brought grain marketing and public intervention back on the agenda of policymakers around the world (Kaminski et al. 2014). This is partly driven by the lack of confidence in free markets and the competitive behavior of traders (Osborne 2005; Sitko and Jayne 2014) and a growing fear for the political economy of food prices (Arezki and Brückner 2011; Brückner and Ciccone 2011). Governmental interventions in the form of price stabilization programs and trade policies are often made without profound knowledge of the marketing system. "Under these circumstances, [...] interventions [are likely to] impair the functioning of the system more than they improve it" (Jones 1972, p. 4). Thus, evidence-based research is

\footnotetext{
L. Kornher $(\bowtie)$

Department of Food Economics and Consumption Studies, University of Kiel, Kiel, Germany e-mail: 1kornher@food-econ.uni-kiel.de

F.A. Asante Institute of Statistical Social and Economic Research, University of Ghana, Legon, Ghana e-mail: fasante@ug.edu.gh
} 
indispensable to endow policymakers with adequate information so that they can design successful agricultural policies aimed at enhancing food security.

In this study, Ghana is chosen as a country case study as it is a typical sub-Saharan African country in many respects. Although the country has made considerable progress in poverty alleviation and the fight against hunger over the past 20 years, food price volatility in the country remains among the highest in the world, and seasonal food insecurity prevails in many parts of the country, especially the north (Quaye 2009). On the other hand, Ghanaian markets are at a crossroad. Wheat and rice imports are becoming more important with a growing free-spending middle class. Poultry and fish farming as well as increasing demand for processed food items shifts market shares toward the industrialized food sector. These changes will undoubtedly make an impact on the traditional marketing system.

The empirical literature on grain markets in Ghana is divided. On the one hand, time series econometrics approaches are used to explain the dynamics and variability of wholesale market prices (Alderman and Shively 1996; Shively 1996, 2001) and spatial market integration (Badiane and Shively 1998; Abdulai 2000). All of the above-mentioned studies focus on maize, the most important domestic crop in Ghana. On the other hand, market analyses based on survey data stress the role of the various actors in the value chain. Much of these studies are of qualitative nature and give insights on marketing channels, spatial trade patterns, and transaction costs (Alderman 1992; Armah and Asante 2006).

None of the existing studies examine storage behavior of larger wholesale traders and companies in order to predict national stocking trends, which is the main objective of this chapter. This is of particular importance since wholesale traders play a key role in guaranteeing sufficient food supply throughout the year. The present work fills this gap in the literature by evaluating primary data collected from July to November 2013. This contains quantitative data from a survey among wholesale traders with significant storage capacity on their operation in spatial trade and intertemporal storage. Qualitative interviews were conducted with processing companies, market experts, and other relevant stakeholders. The information is put into context and policy implications are deduced. In doing so, the findings can also be seen as a starting point and input for future research.

\subsection{Price Instability and Trade Patterns}

There is a natural imbalance between the production and consumption of agricultural commodities. More specifically, consumption is primarily stable, while production is highly volatile, in particular in rainfed agricultural systems, which are the predominant type of agricultural system in many African countries. Therefore, commodity prices are subject to natural instability. Besides, the seasonality of production requires intertemporal arbitrage and causes a deterministic price gap between harvest and lean season, owing to the costs arising from storing food between the seasons. 


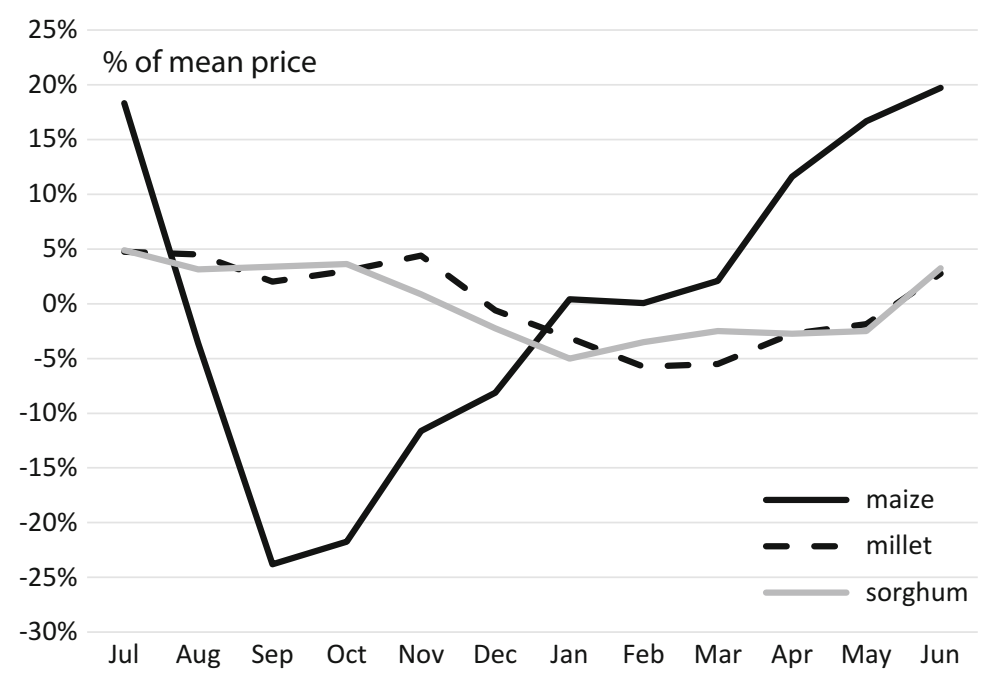

Fig. 23.1 Seasonality of local staples. Source: Authors' computation based on SRID (2014)

Ghana is no exemption in this respect. In order to distinguish irregular price variability from the fixed seasonal trend, we applied an Unobserved Component Model to market-level wholesale price data. The average seasonal price trend for locally produced grains is shown in Fig. 23.1.

Seasonal price instability is highest for maize, with a seasonal gap of more than $40 \%$, followed by millet and sorghum, with around $10 \%$. As proposed by the theory of storage, the inter-seasonal price gap is solely attributed to the cost of storage, since market demand and supply equate prices between two periods. (Williams and Wright 1991). Alternatively, market failures, such as the lack of insurance markets to hedge against price risks, are identified as the reason for limited storage, causing inadequate supply (Newbery and Stiglitz 1981). In line with this, wholesale market prices exhibited at least three major price spikes during the last 15 years. All these spikes were transitory and persisted for 1-2 months only. This hints at temporal supply shortage at the end of the marketing year as a consequence of traders' stockouts (Shively 2001).

Generally, markets within Ghana are found to be well connected, but high transportation costs (due to poor infrastructure) impede full market integration (Abdulai 2000; Quaye and Ameleke 2008; Cudjoe et al. 2010) and link asymmetric adjustment between prices in the central and local markets to inventory adjustment of traders. Therefore, storage decisions are made by taking into account the current and future prices at distant markets, which affect stocking decisions via spatial and temporal arbitrage conditions, as illustrated in Fig. 23.2.

In addition to this, prices are driven by annual domestic production levels and the prospect of speculative exports to neighboring countries (Shively 1996). International prices are likely to have limited impact on domestic price dynamics, 


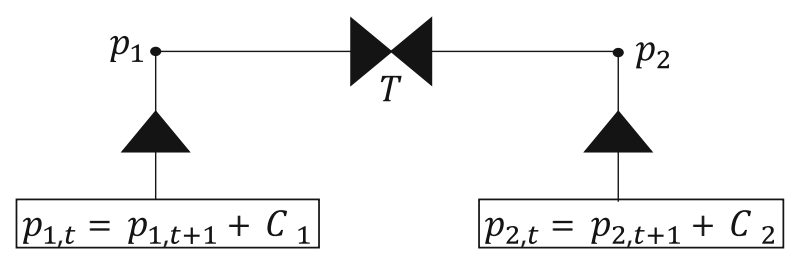

Fig. 23.2 Schematic representation of equilibrium price equations. Source: Adapted from Roehner (1995). Note: $T$ denotes transport costs between market 1 and market 2, while $C_{1}$ and $C_{2}$ are costs of storage in both markets. In theory, spatial and intertemporal arbitrage take place only when price differentials exceed costs. The equilibrium price conditions induce interdependencies between current and future prices in different markets

which is related to the minor relevance of international and regional imports (Conforti 2004; Cudjoe et al. 2010). ${ }^{1}$ By contrast, domestic rice production makes up only about $30 \%$ of the total national supply, causing local rice prices to follow the price dynamics of imported rice without noticeable seasonality (Amikuzuno et al. 2013). A $20 \%$ import tax (10\% for wheat) is imposed on all food commodities; the import duty was suspended for rice in 2008 and 2009. In addition to that, port charges further increase the price of imports and limit the linkage to international prices (Minot 2011).

Last, food markets in Africa are often publicly regulated by national food companies that are also involved in food marketing. Historically, Ghana's agricultural sector has been characterized by large state involvement by the Ghana Food Distribution Cooperation (GFDC) and the Grain Warehousing Company (GWC). ${ }^{2}$ After a short period of complete market liberalization, the National Food Buffer Company (NAFCO) was founded in 2010 to manage the country's emergency and intervention stock. Public stocks are accumulated through market purchases at predetermined prices, while distribution is arranged when market prices exceed target thresholds. Benin et al. (2012) review the operations of NAFCO but are unable to assess its impacts on price dynamics. The main problem is the non-transparency in the operational decision-making by NAFCO. However, target stock levels only represent a small portion of the annual production, and thus NAFCO's purchase and release decisions are unlikely to influence market prices directly. ${ }^{3}$ In contrast, the determination and public announcement of the minimum guaranteed price (paid

\footnotetext{
${ }^{1}$ Food prices are also affected by high inflation pressure, which is considered the major challenge to macroeconomic stability. After a short period of single-digit inflation, the growth rate of the consumer price index has returned to a level of above 10. In accordance with this, the Ghana Cedi (GHS) has depreciated greatly since 2013. The exchange rate is free-floating since 2006, while a redenomination was implemented in 2007 by canceling four digits ( $1 \mathrm{GHS}=10,000 \mathrm{GHC}$ ). GHC: Ghana Cedi; GHS: New Ghana Cedi.

${ }^{2}$ See Sijm (1997) for a comprehensive overview.

${ }^{3} \mathrm{NAFCO}$ stock levels are (1) operation stocks, maize $(30,000 \mathrm{mt})$, rice $(15,000 \mathrm{mt})$, and soybeans $(1000 \mathrm{mt})$, and (2) emergency stocks, maize $(10,000 \mathrm{mt})$, rice $(10,000 \mathrm{mt})$, and soybeans $(1000 \mathrm{mt})$.
} 


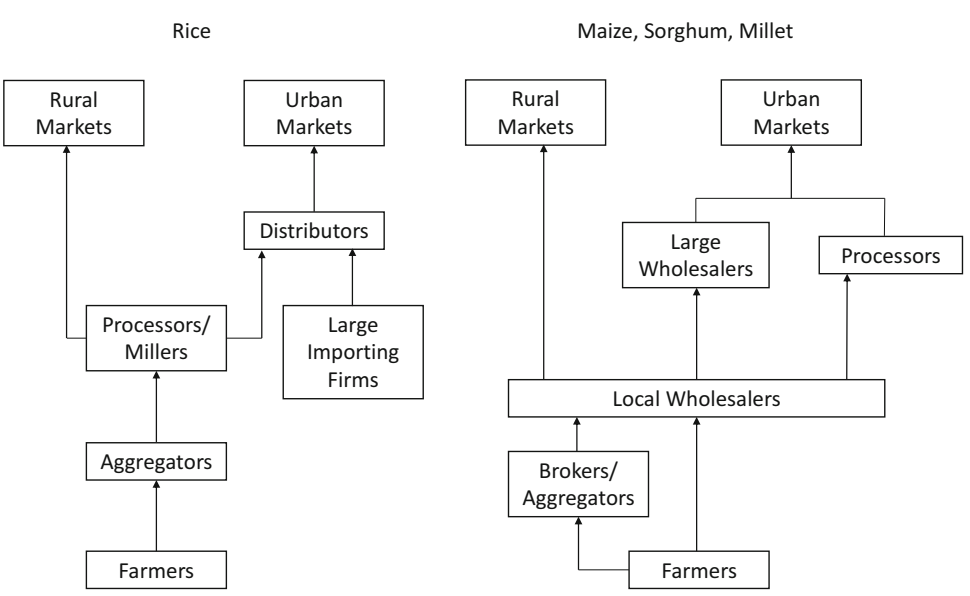

Fig. 23.3 Outline of the value chain of important staples. Source: Authors' illustration

to farmers) have an impact on markets because they can strengthen the bargaining position of farmers in negotiations with traders.

The differences between rice and the three other food commodities-maize, sorghum, and millet-are also reflected in the characteristics of their respective value chains, which are depicted in Fig. 23.3. The distribution of imported rice differs substantially from the marketing of locally produced crops. A few large importing companies divide the majority of the market among themselves (Kula and Dormon 2009). They sell their rice stocks to wholesale traders and supermarkets around the country through their wide local distribution network, but they also run their own outlet stores. Their business activities are highly industrialized and include the operation of large warehouses around the country.

In contrast, the locally produced rice is usually marketed via two distinct channels: first, through aggregators and local wholesalers/processors for sales in rural markets; second, via larger wholesale traders to markets in urban centers. For small and medium size farmers, rural assemblers act as collectors who aggregate surpluses and then sell them to wholesalers in larger towns. Then, wholesale traders sell the produce not only to processors, millers, and retail traders but also directly to consumers. In contrast, larger farmers tend to sell their produce directly to wholesale traders. Maize, sorghum, and millet also pass through the hands of the food industry on their way to becoming final consumer goods; the proportion of formal trade for maize is substantially higher than for millet and sorghum.

Since no value is added to the commodity by having multiple agents involved in the value chain, farmers earn higher profits when selling to wholesale traders directly (Sitko and Jayne 2014). Furthermore, the literature acknowledges that traders play an important role in the functioning of markets in that they provide farmers with inputs and credits (Antons 2010; Sitko and Jayne 2014). There is also little evidence that the market structure of domestic grain trading is noncompetitive, 
apart from the high concentration among few large rice-importing firms (Abdulai 2000; Swinnen et al. 2010; ACET 2014). It is to note that retailers in urban centers usually organize themselves into associations. In doing so, market queens, the elected heads of these female retail trader groups, have manifested themselves as an influential counterpart to wholesale traders (Langyintuo 2010).

Transporting commodities from surplus regions in the middle belt and the northern part of the country to consumption and industrial centers is the major challenge for a long-distance trader. Poor road infrastructure is reflected in the long travel times needed for a relatively short distance. Compared with the wellunderstood structure of the value chain, research about how marketing and trade flows change in the course of a year is still lacking. In other words, it is clear how grain finds its way from producers to consumers, but little is known about how the grain gets from harvest to lean season. Precisely, the agent who stores the grain and the amount and time frame of storage are still unknown. Furthermore, the heterogeneity among wholesale traders is not well considered.

To understand both the spatial distribution and seasonal patterns of storage behavior, it is crucial to start by examining the marketing behavior of farmers. Without providing exact figures on the quantities, farmers' sales of all types of grains exhibit strong seasonality, with a peak after harvest (GSS 2007; Chapoto et al. 2014). From past surveys, it is well known that only a portion of production is formally traded (Armah and Asante 2006; EAT 2012). Therefore, the actual share of stocks held by traders is presumably low (Jones 1972; Alderman 1992). In contrast, the observed increment in the market purchase made by farmers indicates that commodities must be stored somewhere and then sold back to farmers at the end of the marketing year (GSS 2007; Chapoto et al. 2014).

Moreover, there are also massive changes happening in Africa's food marketing. On the one hand, the introduction of modern telecommunication technologies drastically reduces transaction costs (Overa 2006; Tack and Aker 2014) and also eases market access for farmers and small traders. On the other hand, food markets are becoming increasingly industrialized. The number of supermarkets is growing, and with it comes an increasing demand for processed final consumer goods. For this reason, food processing companies are increasing their production volume and claiming a larger share of marketed production. This has wide-ranging consequences on grain marketing. First, the industrialized sector prefers to make purchases in large quantities in order to reduce transaction costs. Second, quality standards gain importance, and this presents challenges to proper handling by value chain actors. Third, retail companies will affect the whole market structure and are likely to occupy a prominent position in the market. The trading sector will be compelled to adjust to these developments in order to preserve its role in the marketing system. 


\subsection{Storage Behavior}

\subsubsection{Description of the Data}

The analysis of storage behavior in Ghana is largely based on a trader survey which provides quantitative data on grain storage and trade. The survey was undertaken as a joint research between the Center for Development Research (ZEF) and the Institute for Statistical, Social and Economic Research (ISSER) at the University of Ghana, Legon, and was held at major market sites in Ghana between August and November 2013. Subsequent to the survey, follow-up telephone interviews were conducted in April and May 2014. Qualitative information from a baseline survey in 2012 and from consulting experts during August and November 2013 enrich and underpin the quantitative data.

First, there are no business directories for traders in Ghana. The lists of traders identified during the research contained invalid phone numbers and information about companies that no longer exist. Therefore, randomization-based sampling techniques were inapplicable. Second, the total number of traders who engage in intertemporal arbitrage is not large, and a larger sample size is considered to be better. For this reason, the sampling was conducted with the intention to create a sample that is representative of the aggregate market behavior. Traders were identified using two unofficial lists: a list of NAFCO contractors published on its webpage and the business directory of Ghana Web, an online news platform. ${ }^{4}$ Contact information of traders was also obtained from governmental publications and other publicly available documents. Furthermore, snowball sampling was used in order to increase the number of respondents.

Generally, traders were contacted by phone and asked about their willingness to participate in the survey. In this way, the response rate was close to $100 \%$. For the follow-up telephone interviews, the respondents of the first survey were contacted. The interviews were structured as follows: First, general information on the enterprise was collected. The second part of the interview aimed at obtaining a general overview of grain trading activities. The heart of the questionnaire was the section about storage activities; in this section, respondents were asked to state their purchases and historical inventory levels during the prior marketing year, that is, 2012/2013. Third, respondents were asked to evaluate specific statements to deduce their perception of risk associated with storage. Last, the interview ended with a survey on the traders' expectations of future price changes, and this section also assessed the traders' market knowledge of tariff rate and historic rainfall and geographical production patterns. Moreover, the telephone interview also asked traders to evaluate specific factors that influence price dynamics and induce market risk. The interview also attempted to obtain information on different cost components.

\footnotetext{
${ }^{4}$ Available at http://www.ghanaweb.com/GhanaHomePage/telephone_directory/.
} 
In total, 36 traders were surveyed in the first round. Only 20 traders were ready to answer to the telephone questionnaire. Several qualitative interviews were also conducted; most notably are interviews with processing companies and practitioners. Since farmers hold a substantial amount of stocks, it is essential to incorporate their behavior into the analysis. The Ghana Living Standard Survey (GLSS) contains an exhaustive section on agriculture, including a section on the seasonality of sales and market purchases. Nevertheless, a few qualitative interviews with farmers and farmer associations were conducted. The ZEF-ISSER Trader Survey is different from most existing trader surveys in two respects. First, this survey focused on interviewing traders who engage in intertemporal arbitrage rather than spatial arbitrage or retailing. Second, related to the first point, intertemporal arbitrageurs who own or rent warehouses are sometimes large companies which are also involved in other businesses. Consequently, the average storage capacity of the respondents is around 10,000 metric tons $(\mathrm{mt})$, and roughly $60 \%$ of the traders had at their disposal storage facilities of $500 \mathrm{mt}$ and above. Apart from inference about the aggregate storage behavior of the market, information on individual stocking trends and trader characteristics allows individual trading behavior to be analyzed in more detail. For this reason, the presentation of research findings from the survey is divided into these two aspects.

\subsubsection{Motives for Trader Storage}

\subsubsection{Speculative Storage}

As predicted by the economic theory, the most prominent motive for storage is the speculation on a future price increase. Speculation is defined as the engagement in risky transactions to benefit from fluctuation in market values. The supply of storage model is extensively discussed in the literature and widely accepted as best way to describe the price dynamics of storable commodities. In brief, storers would choose to provide additional storage as long as the marginal costs of storage do not exceed the expected return from storage in the subsequent period. Generally, it is possible to hedge against any risk associated with storage by trading future contracts or through informal forward contracting. In this way, the price risk is transferred to another institution. However, commodity exchanges and forward contracting are uncommon in most developing countries. Anticipated stocks are a special variant of speculative stocks. They are not held for speculation of higher prices but in anticipation of changes in demand (Minner 2000). Rice traders in Ghana reported keeping anticipated stocks by increasing their stocks before Christmas and Easter to satisfy the increase in demand (ZEF-ISSER Trader Survey 2013).

Speculative storage should not be confused with hoarding, which food traders are often accused of in times of scarcity in the market. The literature defines hoarding as excessive speculation. In theory, hoarding can only arise from imperfect competition (Osborne 2005) or overestimation of price changes (Ravallion 1985). Under the intertemporal arbitrage condition, two major determinants of storage quantity are price expectations and storage costs. Storage costs are high in many 
developing countries due to high interest rates. Ghana is no exemption in this respect (Armah and Asante 2006). Therefore, the amount of stocks in Ghana is likely to be substantially lower than in industrialized countries. Commodity prices in Ghana remain largely driven by seasonality (with the exception of rice), as discussed in the previous section. For this reason, speculative returns are unlikely to be realized from interannual storage. The only justification for speculative stocks at the end of the marketing year is given by uncertainty about the timing of the next harvest (Peterson and Tomek 2005). In contrast, high seasonal price variation generates a great opportunity for traders to benefit from intra-annual price changes. In theory, everyone who possesses stocks can participate in speculation. In reality, however, because speculation binds capital for a longer period, mostly larger and highly liquid enterprises are capable of speculative storage. Indeed, the survey reveals that traders who speculate also diversify their risks by being involved in spatial trading to realize low-risk profits. The respondents also noted that stocks need to be depleted before the end of the marketing year because of an anticipated decline in market prices (ZEF-ISSER Trader Survey 2013). In a typical marketing year, speculative stock levels are expected to be highest when prices are lowest. However, traders prefer to store grain stocks at lower moisture levels. For this reason, maize harvested in August/September in the southern parts of Ghana is usually not kept for long, and existing stocks are depleted again before the next harvest comes in.

\subsubsection{Safety Stocks}

Safety stocks are mainly known from the logistic and supply chain management literature. They are describe as extra stocks that are carried to moderate the risk of stock-outs and associated incapability to satisfy demand. The need for safety stocks arises from uncertainty in demand and supply (Guide and Srivastava 2000). Since inventory holding is costly, safety stocks should be kept at a minimum. Optimal safety stocks are chosen depending on uncertainty in demand, supply, and processing time (Minner 2000). In contrast to speculative stocks, safety stocks are not related to expected future prices but rather to the quantity demanded from the enterprise. In the context of Ghana, two types of market participants are likely to carry safety stocks: processors and animal feed manufacturers and traders, especially retailers. A trader survey conducted during October 2013 by the World Food Program (WFP) found replenishment times of the vast majority of retailers and wholesale traders who responded to be below 1 week (WFP 2014). This indicates that the retailers and wholesale traders attempt to possess sufficient stocks at all times. An explanation may be the high importance of maintaining a continual business relationship by fostering confidence through short-term deliveries. This is evident in that 19 out of 36 respondents ranked "the risk of losing business partners when stopping to supply for 3 month" as a high risk (28/36 as medium or high risk) in the ZEF-ISSER Trader Survey, in particular those traders who are less likely to hold speculative stocks. Retailers hold safety stocks to foster longterm relationship with customers. Consumers who are unable to find what they want in a retail shop will presumably buy the goods elsewhere and are less likely to return to the shop because they expect not to find the goods there again. Fafchamps 
(2004) emphasizes contractual risk in many African countries as the cause of traders keeping large inventories. The risk of late delivery and poor-quality goods drive firms that experience late delivery to hold more than two times more stocks than firms that do not encounter late delivery. Processing firms in Ghana stated that they have enough inventories to sustain production for 1-2 months (ZEF-ISSER Trader Survey 2013). The rise of supermarkets in many African countries in the past years has changed the agro-food system dramatically, causing a shift toward a greater variety of products. Van Donk (2001) projects that the level of safety stocks will increase in order to satisfy the demand for multiple food products at the same time. By definition, safety stock levels are roughly constant throughout the year and will never fall to zero since they are independent of current market prices. However, stock levels are likely to increase by the end of the marketing year as low availability makes input supply uncertain.

\subsubsection{Aggregation Stocks}

The literature on grain marketing in developing countries emphasizes the importance of small-scale traders at village and town level. They play an important role when many farmers do not have access to markets or the costs of traveling to the market are prohibitively high (Sitko and Jayne 2014). As described above, these assembly traders sell their goods to larger wholesale traders, who transport commodities across the country. The aggregation of stocks is an artifact of the characteristics of the value chain. Wholesale traders are likely to collect only larger quantities from village- and town-level markets. Thus, assembly traders aggregate stocks in order to ensure that the transaction process with their trading partners remains efficient. The aggregation of stocks can also occur at central markets when wholesale traders are asked to aggregate large quantities of stocks (more than $1000 \mathrm{mt}$ ) for industrial consumption or purchases made by NAFCO and the WFP, as reported in the survey. This form of stock aggregation is usually performed only when the purchase of the aggregated stocks is guaranteed or even pre-financed. The nature of this form of trade means that stocks will be totally depleted when the target quantity is reached and the goods are delivered to the contractee. There are no reasons for traders not to repeat the procedure several times in the course of a year, yet traders make sure that their stocks are depleted before stocks from the new harvest comes in.

\subsubsection{Operational Costs}

The profitability of storage depends on the costs of operation. Traders incur direct costs from marketing, transport, and storage (Angelucci 2012). Cleaning, drying, and packaging are usually done at the farm level before the produce reaches the market. The main challenge of proper handling is to reduce the moisture content of fresh crops for storage to decrease the incidence of discoloration (Armah and Asante 2006). In some instances, traders support farmers in this process by providing drying facilities or functional bags for adequate storage (Antons 2010). 
Table 23.1 Transport costs on selected roads in May-June 2011

\begin{tabular}{l|l|l|l|l|l}
\hline Route & Bag $(\mathrm{kg})$ & Price/bag & Price/mt & Distance & Cost $\mathrm{mt} / \mathrm{km}$ \\
\hline Kumasi-Accra & 50 & 2.31 & 46.28 & 272 & 0.17 \\
\hline Kumasi-Tamale & 50 & 2.9 & 57.83 & 382 & 0.16 \\
\hline Kumasi-Ejura & 50 & 3 & 60.16 & 98 & 0.61 \\
\hline Kumasi-Nkoranza & 50 & 3 & 60.16 & 150 & 0.4 \\
\hline Kumasi-Wenchi & 50 & 2.31 & 46.28 & 155 & 0.29 \\
\hline Accra-Tamale & 50 & 4.04 & 80.98 & 654 & 0.12 \\
\hline Wenchi-Sunyani & 130 & 6.94 & 53.39 & 97 & 0.56 \\
\hline Wenchi-Techiman & 130 & 4.63 & 35.59 & 29 & 1.23 \\
\hline Wenchi-Accra & 130 & 11.57 & 88.98 & 427 & 0.21 \\
\hline
\end{tabular}

Source: World Bank (2012). Note: Prices converted to GHS with the market exchange rate of 1.74 GHS/USD

The postharvest losses of traders are substantially lower than the losses incurred when produce is kept on-farm since traders usually have at their disposal proper storage facilities and information about appropriate handling. On the other hand, traders have to take additional costs into account. First, storage in warehouses and the treatment of stored commodities are costly. In addition, traders incur the opportunity cost of capital. Last, traders usually bear the costs of transporting goods to their storage facilities and, after storage, to their customers; this includes the loading at point of departure. Exact estimates of transport and storage costs are difficult to obtain and also vary by orders of magnitude and in terms of quality (ZEF-ISSER Trader Survey 2013).

Table 23.1 presents the surveyed transport costs for frequently used destinations in Ghana in 2011. The unit cost of transporting over short distances is more expensive than transporting over standard trade routes between the urban centers Tamale, Kumasi, and Accra. Generally, the transport costs are significant when measured against the wholesale price of a mini bag of maize (50 kg; 30-35 GHS) and maxi bag (130 kg; 40-80 GHS) at that time. During the field survey, loading costs were reported to be 1 GHS for a maxi bag.

The per-unit storage costs cannot be easily calculated. ${ }^{5}$ Therefore, in the interview, traders were asked how much they need to add to the purchase price in order not to make any losses (1) if they buy and immediately sell and (2) if they buy, store for 3 months, and then sell. In the latter case, the reported amount should yield the sole costs of storage without the trader's markup, while in the former case, the reported amount captures mainly the transport costs and also the fixed costs of administration and marketing. The results are reported in Table 23.2.

Transport and administrative costs reported are in gross accordance with the costs estimated by the World Bank (2012). Large firms in Accra and Kumasi reported the smallest amount of storage costs, which is unsurprising. Conversely, it is striking

${ }^{5}$ Due to the large share of fixed costs 
Table 23.2 Transportation and storage costs from trader survey

\begin{tabular}{l|l}
\hline Description & Reported costs \\
\hline \multirow{2}{*}{ Large firms in urban centers } & Storage costs: $12-18$ GHS per ton \\
\cline { 2 - 2 } & Transport and admin costs: $25-30 \mathrm{GHS}$ per ton \\
\hline \multirow{2}{*}{ raders in Brong-Ahafo } & Storage costs: $1-1.5 \mathrm{GHS}$ per $50 \mathrm{~kg}$ \\
\cline { 2 - 2 } & Transport and admin costs: $1-2 \mathrm{GHS}$ per $50 \mathrm{~kg}$ \\
\hline \multirow{2}{*}{ Traders in the Northern Region } & Storage costs: $2-8$ GHS per $100 \mathrm{~kg}$ \\
\cline { 2 - 2 } & Transport and admin costs: $5-12 \mathrm{GHS}$ per $100 \mathrm{~kg}$ \\
\hline
\end{tabular}

Source: ZEF-ISSER Trader Survey (2013). Note: Differences across crops could not be observed, but the sample size for rice and soybeans was small; traders choose their preferred unit to report the costs

that the transport and administration costs are much higher than the storage costs for 3 months. ${ }^{6}$ A comparable proportional relationship between the transport and storage costs can also be found in other studies (e.g., Angelucci 2012; EAT 2012; Angelucci et al. 2013). From our own survey, it can be deduced that the total operational costs constitute between 5 and $50 \%$ of the purchase price.

In Ghana and elsewhere, it is generally observed that storage facilities are built to exploit economies of scale (Monterosso et al. 1985) or the proximity to processing companies in urban centers (EAT 2012). Benirschka and Binkley (1995) explain this phenomenon by the presence of opportunity costs that decrease with distance to the producing market. In consequence, market supply takes place in a sequential manner. Firms located far away from the market release their stocks only after those firms located closer to the market have fully released their stocks. This implies that as soon as grain supply in production regions is exhausted, grains will be transported back from urban centers to rural markets. In this way, transport costs are incurred twice: initially when grain is shipped from rural to urban areas after harvest and subsequently in the reverse direction during the hunger season (Barrett 1996).

Taking into account the high costs of transport, traders need to increase their sales price in order to break even. In light of this, seasonal price changes of around $50 \%$ in selected years appear quite reasonable, and thus transport costs are a potential driver of the high seasonality of prices. Conversely, the costs of storage alone (excluding transportation costs) cannot account for the strong seasonality in prices.

\subsubsection{Aggregated Results: Seasonality in Storage and Trade}

The aggregated turnover of the survey respondents represents a significant portion of the total quantity marketed for rice and maize only. ${ }^{7}$ The figures presented in Table 23.3 suggest that sorghum, millet, and soybeans pass through the hands of

\footnotetext{
${ }^{6}$ The figures should be interpreted cautiously with respect to the total size of the cost reported.

${ }^{7}$ Turnover is the total purchase of a trader within one marketing year.
} 
Table 23.3 Stylized facts of grain markets and survey

\begin{tabular}{l|l|l|l|l}
\hline & Maize & Rice & Sorghum/millet & Soya \\
\hline National consumption 2013 (FAO GIEWS) & $1,700,000$ & 950,000 & 450,000 & 150,000 \\
\hline National production 2013 (FAO GIEWS) & $1,800,000$ & 300,000 & 470,000 & 150,000 \\
\hline Industrial use & 20 & n.a & n.a. & 70 \\
\hline$\%$-formally traded & 50 & $>80$ & $<20$ & 85 \\
\hline No. of traders in sample & $29(+2)$ & $14(+8)$ & 3 & 11 \\
\hline Turnover captured by the survey & 94,000 & 377,000 & - & 7400 \\
\hline
\end{tabular}

Note: Figures for soya are from MoFA (2013). The quantities for soybeans refer to raw commodities. Instead, soybean cake and oil are also imported. Estimates on industrial use are taken from EAT (2012). () indicate number of traders that purchase yellow maize and imported rice, respectively

wholesale traders less often than maize and rice. In addition, soybeans are used for human consumption only to a small extent. The figures indicate that processing firms, rather than traders, are largely involved in the storage of sorghum, millet, and soybeans. Therefore, the subsequent discussion is limited to maize and rice.

The sample cannot be considered representative with regard to the composition of the traders. Large wholesale companies are overrepresented, while the portion of traders with a capacity of a few dozen bags was relatively too small. The respondents of the survey purchase and sell commodities to different market actors. While the vast majority of the respondents buys their commodities from farmers or aggregators, about half of the respondents also purchases from other wholesale traders. With respect to sales, only seven respondents sell to consumers directly. In contrast, the vast majority interacts with other wholesalers, processing companies, and retail traders (ZEF-ISSER Trader Survey 2013).

The first indication of the seasonal variability of stocks is shown in Fig. 23.4, which illustrates the best time to stock in and to release stocks as specified by the survey respondents. For maize, stocking-in mostly takes place from August to September and November to January. This largely corresponds to the time of harvest, and thus the time of the year at which prices are lowest. Interestingly, some traders continue to build stocks throughout the year. In line with this, stock releases also occur throughout the year. Nevertheless, most traders prefer to sell their maize stocks from April to June in order to benefit from higher prices at that time. Results for rice are different. Stocks of imported rice exhibit less intra-annual variation apart from the fact that stocks are built before Christmas to satisfy the increasing demand. In contrast, traders stock up local rice between November and January with the intention to sell the local rice between March and June; this exemplifies the seasonality of rice prices.

Seasonal variation of actual stocks is deduced from the survey in the following way. First, stock levels of respondents are interpolated in order to fill gaps in the questionnaire. Second, estimated stock levels are aggregated by commodity. In doing so, large wholesale traders carry over-proportional weight, while stocks of smaller traders hardly change aggregated stock level. Figure 23.5 shows the 

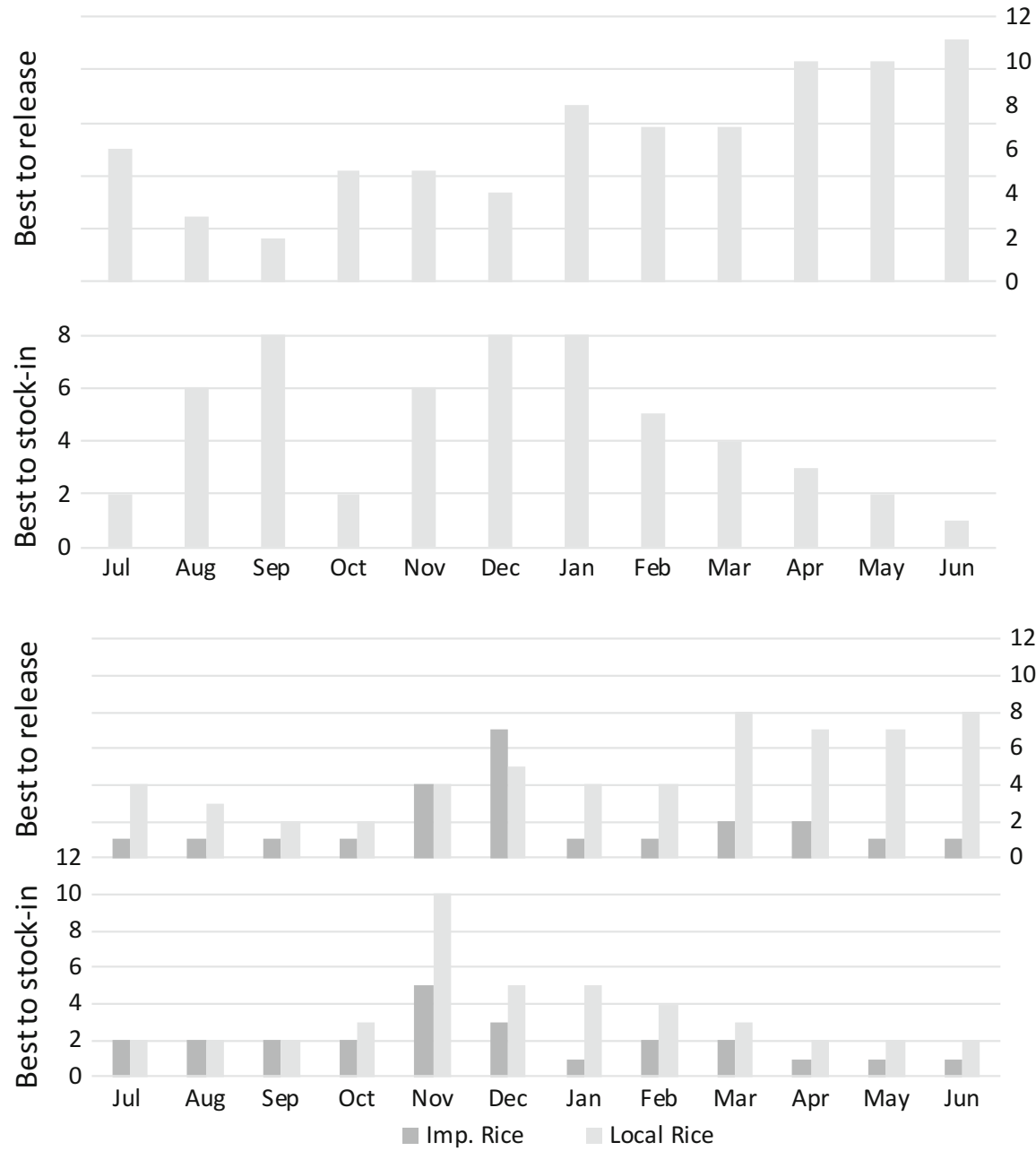

Fig. 23.4 Best time to stock in and stock out (no. of respondents). Source: ZEF-ISSER Trader Survey (2013)

seasonality of the observed stocks within the survey period. The estimates are in accordance with the preferred time of stocking-in and releasing stocks.

For maize, this is an increasing function until February/March. Maize stocks were accumulated in the course of the year and distributed toward the new harvest season. Over the survey period, maize stocks vary significantly between 10,000 and 45,000 tons. It seems that on-farm stocks dominate at the beginning of a marketing year, and trader stocks take over only in the last few months before the next harvest. This observation is different from what is known about traders' storage pattern in other countries, whereby stocks are usually highest after harvest and decline 

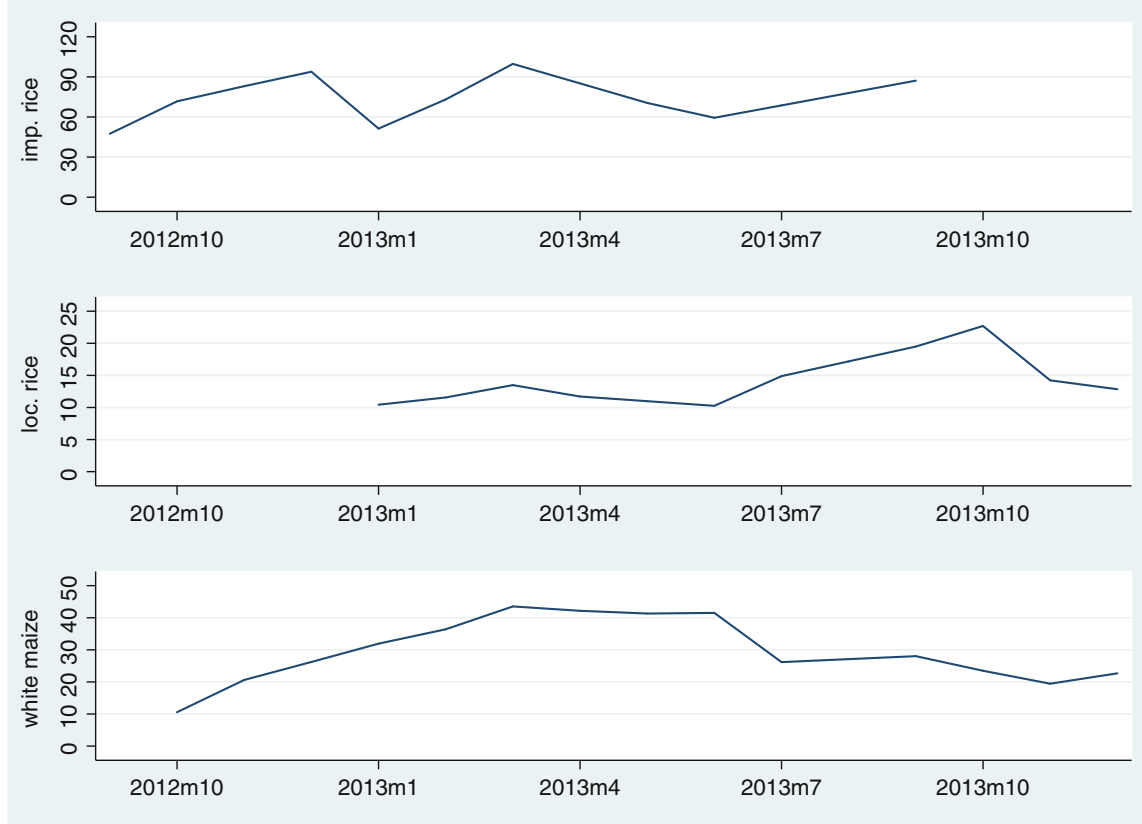

Fig. 23.5 Aggregated stock trend (in $1000 \mathrm{mt}$ ). Source: ZEF-ISSER Trader Survey (2013)

throughout the year. ${ }^{8}$ From the qualitative interviews, we know that the safety stocks of maize processing companies are able to sustain their total production for 1-2 months. With the knowledge that $20 \%$ of the total national consumption is used for industrial use, the level of stocks held by processors is estimated to be 40,000 $\mathrm{mt}$. Similarly, we can estimate the amount of stocks held by retail traders from the daily consumption needs of the market. ${ }^{9}$ Assuming that retailers hold enough stocks for 5 days, the national aggregate for retail trader stocks would be around 12,000 mt. Therefore, even if the survey respondents represented a large share of the market, wholesale traders would still carry the largest amount of maize stocks compared to other market participants.

Unlike maize, rice stocks did not show a similarly strong seasonality. Imported rice stocks were built up before Christmas and Easter and declined as a result of releases during festival time. Local rice stocks did not exhibit similar peaks around Christmas and Easter. On the contrary, the stock level reached its lowest point in June, and before that, rice was constantly accumulated. Similar to maize, local rice is processed, and millers are expected to also hold stocks throughout the year. The

\footnotetext{
${ }^{8}$ For example, see private stock data on South Africa by South African Grain Information Service (SAGIS).

${ }^{9}$ This is achieved by dividing the amount of maize marketed (850,000 mt) by 365 days.
} 
same applies to both the imported and local rice stocks of retail trader. However, wholesale rice traders carry by far the largest amount of stocks throughout the whole year. Due to imports constituting a large share of the total rice stocks, rice stored by farmers is not important for rice.

\subsubsection{Micro Results: Heterogeneity of Traders}

Seasonal patterns of storage provide interesting insights into the market behavior on the national scale. The diversity of storage motives, as elaborated earlier, suggests heterogeneity in storage strategies among traders or groups of traders. In this section, we assess whether these differences are actually observable and discuss possible explanations. Individual stock-holding patterns by traders are shown in Figs. 23.6, 23.7, and 23.8.

A single common storage strategy cannot be observed among maize traders. By contrast, similarities in the behaviors of imported rice traders can be observed. None of the traders have entirely depleted their stocks in the course of the observation period. Furthermore, all traders tended to increase their stock level toward the end of 2013. Like maize, heterogeneous patterns can be observed in the stock level of local rice, apart from an increase in the stock level between September and December 2013, which is common for all traders. Overall, there are similarities between the
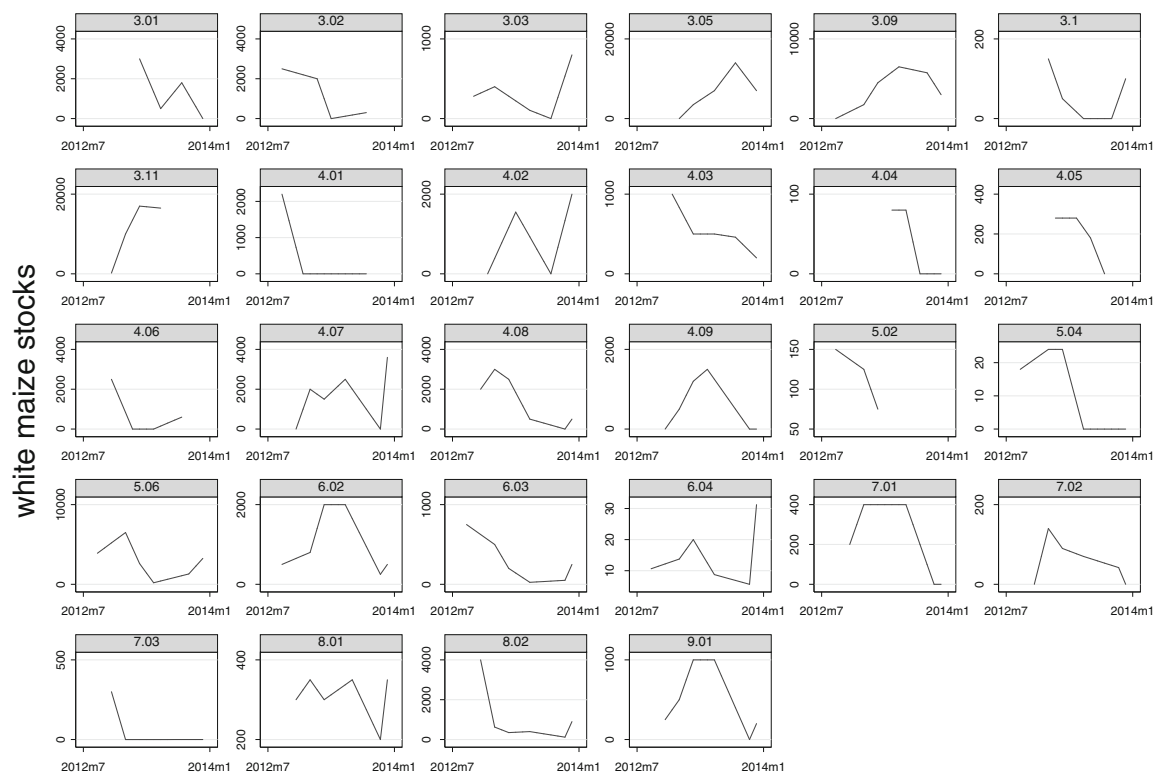

Graphs by Respondent ID

Fig. 23.6 Stocks by respondent (white maize). Source: ZEF-ISSER Trader Survey (2013) 

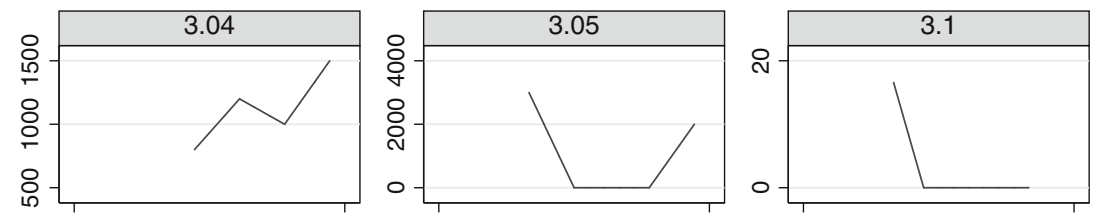

2012m7

2014m1 2012m7

2014m1 2012m7

2014m1
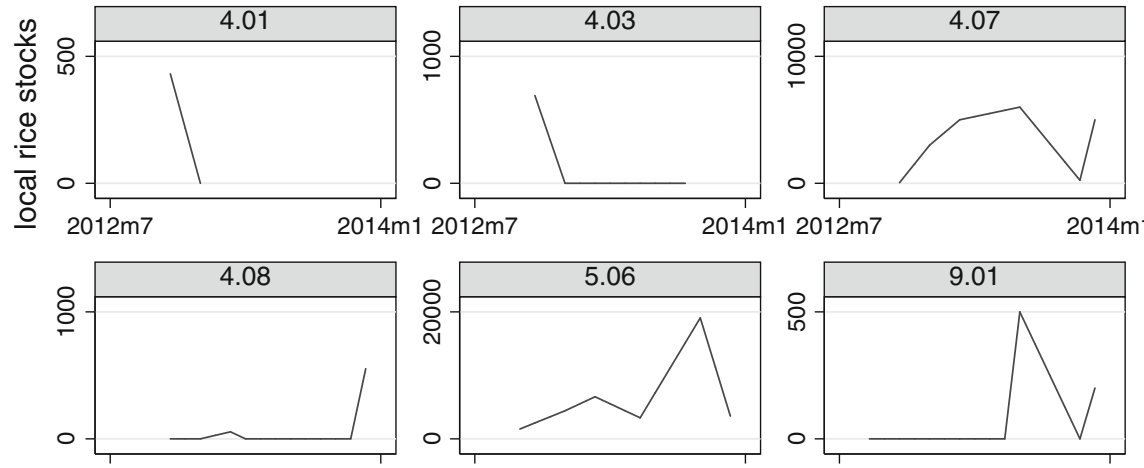

$2012 m 7$

$2014 m 12012 m 7$

$2014 m 12012 m 7$

$2014 m 1$

Graphs by Respondent ID

Fig. 23.7 Stocks by respondent (local rice). Source: ZEF-ISSER Trader Survey (2013)
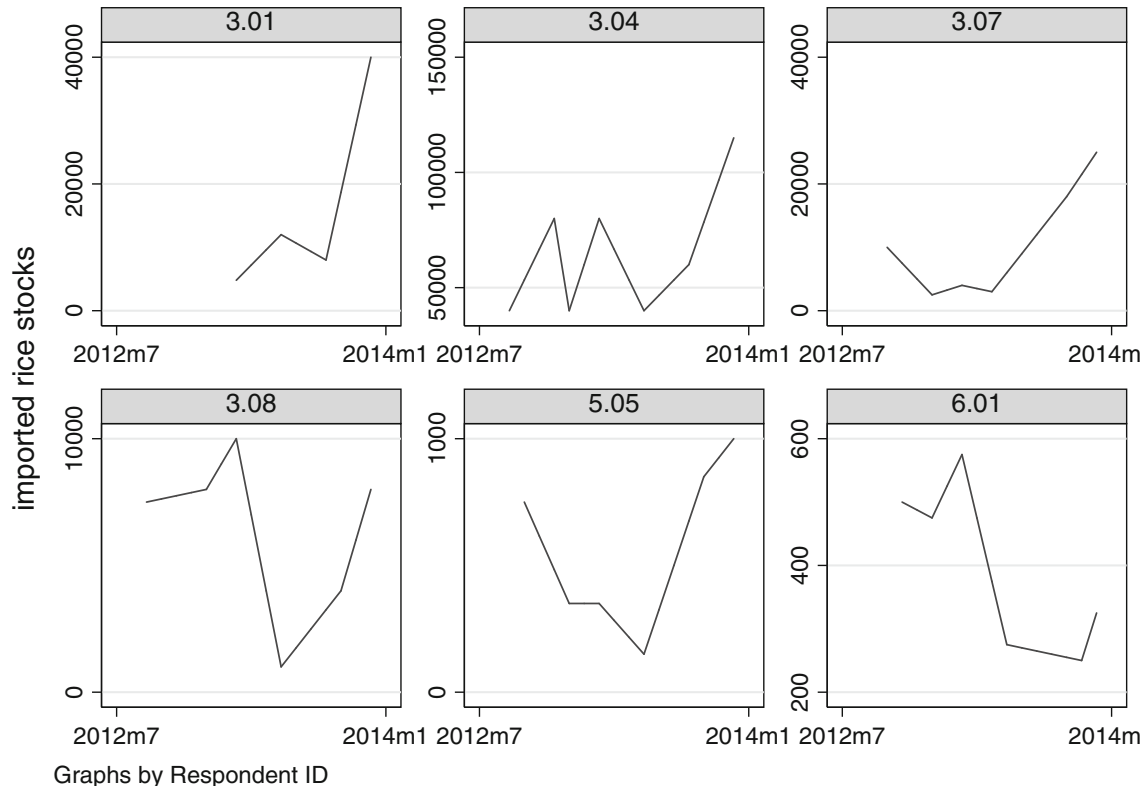

Fig. 23.8 Stocks by respondent (imported rice). Source: ZEF-ISSER Trader Survey (2013) 
stocking trends of maize and local rice, while storage of imported rice seems to be determined by other factors.

From the discussion about storage motives, we recognize two distinct types of traders: aggregators, who accumulate predetermined amounts of stocks for delivery to their customers on a mutually agreed date; and speculators, who hold stocks to benefit from seasonal variation in prices. By contrast, we do not observe any stock trends which imply that stocks are held purely as safety stocks. This could be because the sample includes large wholesale traders but not retailers. However, it may also be because parts of the grain stocks, in particular of imported rice, are safety stocks that are held with the intention of guaranteeing continuous distribution.

To further analyze stocking patterns, we use a simple approach to differentiating stocking strategies. We distinguish between a U-shape and a reverse U-shape storage curve. A reverse U-shape curve represents the holding of stocks until mid 2013, which hints at a speculative strategy. Conversely, a U-shape curve implies purchases in late 2012 including more or less immediate sales and restocking in late 2013. The latter better describes the stocking pattern of an aggregator. ${ }^{10}$

Extrapolating on the stocking strategy from the seasonal variation in stocks only rests on fragile foundations. Instead, it is critical to understand what drives traders to follow a particular strategy that maximizes their profits or expected utility. In other words, what makes a trader a speculator and what makes them an aggregator or distributor. In this study, we will not go into detail on this, but we will briefly outline possible explanations, as illustrated in Fig. 23.9. Further research is necessary to validate the explanations.

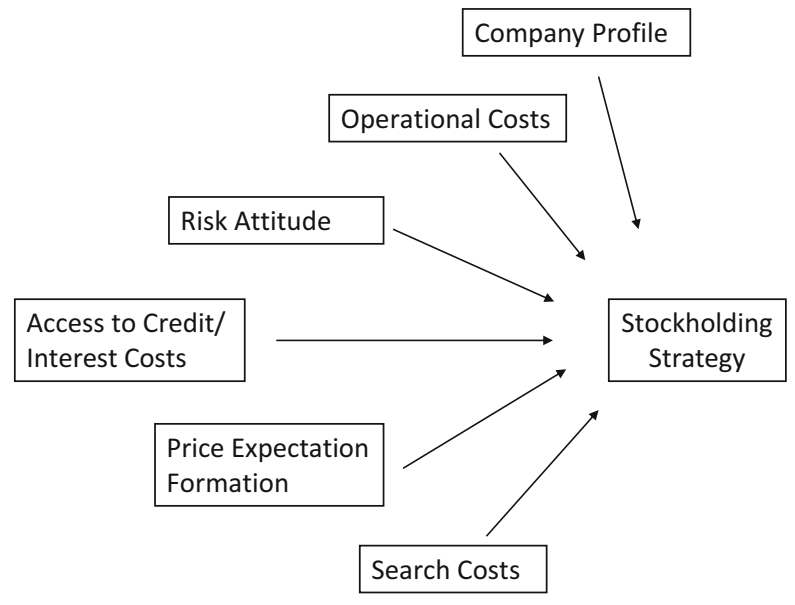

Fig. 23.9 Determinants of the stock-holding strategy. Source: Authors' illustration

\footnotetext{
${ }^{10}$ In total, we identify (U shape/reverse U shape) for maize (9/15), local rice (5/3), and soya (8/1).
} 
The profile of a trading company includes characteristics like the field of business, legal status, and the size of the company. Many trading companies maintain other businesses besides their grain storage activity. These businesses can be closely related to storage, but this is not a sufficient condition for commodity trading activities. For instance, many rice importers in Ghana also engage in importing a variety of other goods (e.g., motorcycles). Other than that, commodity trading is considered to be an investment which yields a return on asset, like buying shares of a company. The main challenge of concentrating solely on grain trading is the cyclical nature of business earnings, which makes it particularly difficult for small traders to move into intra-annual speculations because returns are only realized at the end of the season. On the other hand, a trader in a company owned by many shareholders does not have the pressure to generate continuous revenue to make money for living. On the same account, large firms are more likely to have at their disposal sufficient financial resources to survive one or multiple years with limited business success.

Transportation and storage costs usually are the main components of operational costs. Theoretically, one would expect aggregators to have a comparative advantage in minimizing loading and transportation costs since they generate revenue from the collection and transportation of commodities only. This involves having dense networks of suppliers at village level. On the other hand, speculators are expected to face lower costs in storage activities, including the access to capital and the interest costs incurred when borrowing money to buy grains in bulk after the harvest. Differences in transportation and storage costs incurred by traders could also be attributed to traders owning warehouse structures and/or vehicles for transportation. In this case, traders are relieved of paying interest to the banks and face lesser costs of storage.

Most definitely, risk attitudes play a prominent role in business activities. Stocking commodities over a longer time period with uncertainty about future prices is riskier than spatial trading, and risk aversion will result in the reduction of storage levels when futures markets do not exist (Sarris 1984). Conversely, traders inclined to taking risks are more likely to engage in speculation without being fully certain about future prices. The heterogeneity of risk attitudes of traders has not been extensively discussed in the risk literature, which has mainly focused on farmers and small-scale traders. However, the diversity of the ownership structure of trading companies is likely to be correlated with and implies the presence of heterogeneous risk preferences.

Apart from storage costs, the classical supply of storage model links stocking decisions to expectations of future prices (Williams and Wright 1991). The traditional version of the competitive storage model is built on the rational expectation hypothesis, which implies that market actors perfectly process all available information that is relevant for the formation of prices. All associated errors are therefore considered to be random (Gustafson 1958; Muth 1961). However, the literature on economic behavior of agents identifies at least four different types of price expectations: naive, adaptive, quasi-rational, and rational expectations. The types of price expectations differ by the amount of information which is taken into account 
to predict the future price. The heterogeneity in expectation formation processes among traders yields a variety of views on what the future will bring and may explain why traders carry different amounts of stocks at any given time.

Furthermore, Chavas (1999) argues that gaining market information is costly and heterogeneous expectations are caused by the costs and benefits specific to an individual. On the same account, the search for price information itself can be costly. These costs reflect a trader's specific ability to process market information or the degree the trader is interlinked with other value chain actors in the marketing system, which makes it easier for him to collect information. Lower search costs allow a trader to undertake a higher investment in searching, resulting in the trader finding the best deal (Stigler 1961). In the context whereby prices are dispersed and market information is not easily accessible due to limited quality of market information systems or digital infrastructure, variation in knowledge ability is possible and might explain the different storage strategies used by traders to maximize profits or utility from their storage operations (Jensen 2007; Tack and Aker 2014).

\subsection{Discussion and Policy Implications}

In this chapter, the intertemporal storage behavior of wholesale traders is analyzed and discussed. Unlike earlier studies, traders are found to hold a substantial amount of grain stocks, especially toward the end of the marketing year. With the exception of imported rice, most of these stocks are held by traders for speculative reasons, with the intention of profiting from the seasonal increase in prices. Other wholesalers accumulate stocks in large quantities for sale to industrial clients. Due to the likely decline in prices with the incoming harvest in July/August, traders attempt to deplete their stocks before prices drop. However, this is often not possible in a bumper crop year. Carrying stocks over to the next marketing year is usually associated with losses. Thus, annual carry-over stocks are kept at a minimum. In contrast to maize and local rice, imported rice stocks exhibit less variation throughout the year. These stocks are built up in anticipation of demand peaks. Apart from trader storage, safety stocks are carried by industrial producers to guarantee that their production can be maintained even when facing delivery problems. Safety stocks are also held by retailers to satisfy market demand throughout the year.

An additional finding of the survey is the heterogeneity of storage strategies among traders. In other words, the respondents' individual stocking trends did not show a uniform pattern. Several explanations have been discussed based on the theory of storage, including heterogeneity in risk attitudes, operational costs, firm characteristics, and price expectations. Future research may consider verifying the relevance of these explanations in the context of Ghana.

It is not within the scope of the study to give a definite answer as to why price dynamics in Ghana are characterized by strong seasonal variation and occasional price spikes. The price spikes at the end of the marketing year may be attributed to trader stock-outs induced by the high risk of making losses if stocks are carried into the next year. High seasonal price increases often reflect high real transaction 
costs that are related to physical infrastructure, and the increases also explain price dispersion across space and time. In particular, if storage structures are located far away from production markets, then commodities will have to be transported over large distances when storing stocks as well as when releasing stocks (Barrett 1996).

Hence, effectively mitigating seasonal price variability appears to be a challenge. In particular, it is important to bear in mind that seasonal price increases are also necessary to make storage profitable, given the high costs of storage and transportation. However, the large share of stocks held by private traders suggests that their behavior can affect the market dynamics. Understanding the drivers of their behavior can be helpful in employing the right tools to enhance private storage. Private storage could be enhanced by investing in infrastructure and storage facilities located close to production areas or by providing a warehouse receipt system that enables traders and farmers to store relatively small quantities without the risk of their goods deteriorating. Alternatively, better and cheaper access to market information and facilitating hedging against price risk through organized commodity exchanges may potentially incentivize investments in commodity storage.

Acknowledgments The authors acknowledge financial support from the Federal Ministry of Economic Cooperation and Development of Germany (Research Project on Commodity Price Volatility, Trade Policy and the Poor). The ZEF-ISSER survey was conducted with support from Linus Linnaeus Tannor and Hanan Abdullah. The authors are also greatly indebted to all the participants who were willing to contribute to the survey.

Open Access This chapter is distributed under the terms of the Creative Commons AttributionNoncommercial 2.5 License (http://creativecommons.org/licenses/by-nc/2.5/) which permits any noncommercial use, distribution, and reproduction in any medium, provided the original author(s) and source are credited.

The images or other third party material in this chapter are included in the work's Creative Commons license, unless indicated otherwise in the credit line; if such material is not included in the work's Creative Commons license and the respective action is not permitted by statutory regulation, users will need to obtain permission from the license holder to duplicate, adapt or reproduce the material.

\section{References}

Abdulai A (2000) Spatial price transmission and asymmetry in Ghanaian maize market. J Dev Econ 63(3):327-349

ACET (2014) The role of agricultural supply chains in ECOWAS countries. Technical report, African Center for Economic Transformation (ACET). Paper presented at the Annual Meeting of the African Region Chapter of the Econometric Society (AES), Addis Ababa, July 16-19, 2014

Alderman H (1992) Food security and grain trade in Ghana. Working Paper 28. Cornell Food and Nutrition Policy Program, Washington, DC

Alderman H, Shively GE (1996) Economic reform and food prices: evidence from markets in Ghana. World Dev 24(3):521-534

Amikuzuno J, Issanaku G, Daadi EB (2013) Price transmission between imported and local rice markets in a liberalised economy: are Ghana's rice wars just much I do about nothing? J Econ Sustain Dev 4(20):109-119 
Angelucci F (2012) Analysis of incentives and desincentives for maize in Ghana. Technical notes series. MAFAP, FAO, Rome

Angelucci F, Asante-Poku A, Anaadumba P (2013) Analysis of incentives and disincentives for rice in Ghana. Technical notes series. MAFAP, FAO, Rome

Antons D (2010) Embedded services provided by traders in the maize value chain in Brong-Ahafo. Technical report. Market-oriented Agriculture Programme (MOAP)

Arezki R, Brückner M (2011) Food prices and political instability. IMF Working Paper 11/62. International Monetary Fund (IMF), Washington, DC

Armah PW, Asante F (2006) Traditional maize storage systems and staple-food security in Ghana. J Food Distrib Res 37(01)

Badiane O, Shively GE (1998) Spatial integration, transport costs, and the response of local prices to policy changes in Ghana. J Dev Econ 56(2):411-431

Barrett CB (1996) Urban bias in price risk: the geography of food price distributions in low-income economies. J Dev Stud 32(6):830-849

Benin S, Johnson M, Jimah K, Taabazuing J, Tenga A, Abokyi E, Nasser G, Aharbo G, Owusu V (2012) Evaluation of four special initiatives of the Ministry of Food and Agriculture, Government of Ghana. Special report. International Food Policy Research Institute (IFPRI), Accra

Benirschka M, Binkley JK (1995) Optimal storage and marketing over space and time. Am J Agric Econ 77(3):512-524

Brückner M, Ciccone A (2011) Rain and the democratic window of opportunity. Econometrica 79:923-947

Chapoto A, Houssou N, Mabiso A, Cossar F (2014) Medium and large-scale farmers and agricultural mechanization in Ghana: survey results. Technical report. Ghana Strategy Support Program (GSSP) - International Food Policy Research Institute (IFPRI)

Chavas JP (1999) On the economic rationality of markets participants: the case of price expectations in the U.S. pork market. J Agric Resource Econ 24:19-37

Conforti P (2004) Price transmission in selected agricultural markets. FAO Commodity and Trade Policy Research Working Papers 7. Food and Agricultural Organization, Rome

Cudjoe G, Breisinger C, Diao X (2010) Local impacts of a global crisis: food price transmission, consumer welfare and poverty in Ghana. Food Policy 35(4):294-302

EAT (2012) The market for maize, rice, soy, and warehousing in northern Ghana. Technical report. Enabeling Agricultural Trade (EAT), USAID

Fafchamps M (2004) Market Institutions in sub-Saharan Africa. MIT Press, Cambridge, MA

GSS (2007) Ghana Statistical Service (GSS). Ghana Living Standard Survey Round 5 (GLSS V)

Guide VDR, Srivastava R (2000) A review of techniques for buffering against uncertainty with MRP systems. Prod Plann Control Manage Oper 11(3):223-233

Gustafson RL (1958) Carryover levels for grains: a method for determining amounts that are optimal under specified conditions. Technical bulletin. United States Department of Agriculture

Jensen RT (2007) The digital provide: information (technology), market performance, and welfare in the south Indian fisheries sector. Quart J Econ 122(3):879-924

Jones W (1972) Marketing staple food crops in Tropical Africa. Monograph, Cornell

Kaminski J, Christiaensen L, Gilbert C, Udry C (2014) The end of seasonality? New insights from sub-Saharan Africa. Policy Research Working Paper 6907. World Bank, Washington, DC

Kula O, Dormon E (2009) Global food security response Ghana rice study. microReport 156, USAID

Langyintuo AS (2010) Grain distribution in Ghana under imperfectly competitive market conditions. Paper presented at the 2010 AAAE Third Conference/AEASA 48th Conference, Cape Town, South Africa, September 19-23, 2010

Maxwell DM (2013) Food security in the frontier: seasonal hunger and poverty in Bangladesh. Available at http://dx.doi.org/10.2139/ssrn.2283880

Minner S (2000) Strategic safety stocks in supply chains, Number 490 in Lecture Notes in Economics and Mathematical System. Springer, Berlin 
Minot N (2011) Transmission of world food price changes to markets in sub-Saharan Africa. Discussion Papers 1059. International Food Policy Research Institute (IFPRI), Washington, DC MoFA (2013) Agriculture in Ghana - facts and figures. Technical report. Ministry of Food and Agriculture (MoFA) - Statistics, Research and Information Directorate (SRID)

Monterosso CDB, Wright CL, Lacerda MCS, Ofugi N (1985) Grain storage in developing areas: location and size of facilities. Am J Agric Econ 67(1):101-111

Muth JF (1961) Rational expectations and the theory of price movements. Econometrica 29(3):315-335

Newbery DMG, Stiglitz JE (1981) The theory of commodity price stabilization: a study in the economics of risk. Oxford University Press, Oxford

Osborne T (2004) Market news in commodity price theory: application to the Ethiopian grain market. Rev Econ Stud 71(1):133-164

Osborne T (2005) Imperfect competition in agricultural markets: evidence from Ethiopia. J Dev Econ 76(2):405-428

Overa R (2006) Networks, distance, and trust: telecommunications development and changing trading practices in Ghana. World Dev 34(7):1301-1315

Peterson HH, Tomek WG (2005) How much of commodity price behavior can a rational expectations storage model explain? Agric Econ 33(3):289-303

Quaye W (2009) Food sovereignty and combating poverty and hunger. Tailoring Biotechnol 3(2):69-78

Quaye W, Ameleke G (2008) Sorghum market integration study in Ghana. Ghana J Agric Sci 41(1):35-47

Ravallion M (1985) The information efficiency of traders' price expectations in a Bangladesh price market. Oxford Bulletin of Economics and Statistics, Department of Economics, University of Oxford 47(2):171-184

Roehner BM (1995) Theory of markets - trade and space-time patterns of price fluctuations. A study in analytical economics. Springer, Berlin

Sahn DE, Delgado C (1989) Seasonal variability in Third World agriculture - the consequences for food security. Chapter: The nature and implications for market intervention of seasonal food price variability. John Hopkins University Press, Baltimore, MD, pp 179-195

Sarris AH (1984) Speculative storage, futures markets, and the stability of commodity prices. Econ Inq 22(1):80-97

Shively GE (1996) Food price variability and economic reform: an arch approach for Ghana. Am J Agric Econ 78(1):126-136

Shively GE (2001) Price thresholds, price volatility, and the private costs of investment in a developing country grain market. Econ Model 18(3):399-414

Sijm JPM (1997) Food security and policy interventions in Sub-Saharan Africa. Thesis Publisher Amsterdam, Amsterdam

Sitko NJ, Jayne T (2014) Exploitative briefcase businessmen, parasites, and other myths and legends: assembly traders and the performance of maize markets in eastern and southern Africa. World Dev 54(C):56-67

SRID (2014) Statistics, Research and Information Directorate (SRID) at the Ministry of Food and Agriculture, Ghana

Stigler GJ (1961) The economics of information. J Polit Econ 69:213

Swinnen JFM, Vandeplas A, Maertens M (2010) Governance and surplus distribution in commodity value chains in Africa. In: Sarris A, Morrison J (eds) Food security in Africa - market and trade policy for staple foods in eastern and southern Africa. Edward Elgar, Cheltenham

Tack J, Aker JC (2014) Information, mobile telephony, and traders' search behavior in Niger. Am J Agric Econ 96(5):1439-1454

Tadesse G, Guttormsen AG (2011) The behavior of commodity prices in Ethiopia. Agric Econ 42(1):87-97

Vaitla B, Devereux S, Swan S (2009) Seasonal hunger: a neglected problem with proven solutions. PLoS Med 6(6), e1000101 
van Campenhout B, Lecoutere E, D’Exelle B (2015) Inter-temporal and spatial price dispersion patterns and the well-being of maize producers in southern Tanzania. J Afr Econ 24(2):230-253

van Donk DP (2001) Make to stock or make to order: the decoupling point in the food processing industries. Int J Production Econ 69(3):297-306

WFP (2014) Market assessment in Fentantaa, Egyeikrom and Ampain refugee camps. Technical Report. World Food Program (WFP) - Ghana Country Office

Williams JC, Wright BD (1991) Storage and commodity markets, 1st edn. Cambridge University Press, Cambridge

World Bank (2012) Agribusiness indicators: Ghana. Economic and sector work 68163

ZEF-ISSER Trader Survey (2013) Joint project by the Center for Development Research (ZEF) and the Institute for Statistical, Social and Economic Research (ISSER) 